\title{
Using ferric sulfate, sodium hydroxide, and chitosan to harvest marine microalgae Chlorella vulgaris and recycling the culture medium
}

Jinling Cai ( $\square$ jinlingcai@tust.edu.cn )

Tianjin University of Science and Technology

Yu Wang

Tianjin University of Science and Technology

Chenchen Feng

Tianjin University of Science and Technology College of Biotechnology

Xinzhi Zhang

Tianjin University of Science and Technology

\section{Research Article}

Keywords: Microalgae, Flocculation, Chitosan, Culture medium recycle

Posted Date: February 19th, 2021

DOl: https://doi.org/10.21203/rs.3.rs-164732/v1

License: (a) (i) This work is licensed under a Creative Commons Attribution 4.0 International License. Read Full License 


\section{Abstract}

Microalgae are widely used in biofuels, medicine, food, and feed industries. However, harvesting microalgal biomass is a major difficulty that hinders their industrial application. In this study, three flocculants (ferric sulfate, sodium hydroxide, and chitosan) were used to harvest the marine microalga Chlorella vulgaris, and floc characteristics including flocculation efficiency, concentration factor, and flocs morphology were studied. The results showed that the tested flocculants can efficiently harvest $C$. vulgaris. The flocculation efficiencies of ferric sulfate $(0.9 \mathrm{~g} / \mathrm{L})$, sodium hydroxide $(0.6 \mathrm{~g} / \mathrm{L})$, and chitosan $(30 \mathrm{mg} / \mathrm{L})$ were $93.4 \% \pm 0.8 \%, 96.5 \% \pm 0.6 \%$, and $98.8 \% \pm 1.3 \%$ within 70,100 , and 12 min, respectively. The total carbohydrates, proteins, and lipids contents in $C$. vulgaris were not influenced by the test flocculants after harvesting. When compared with fresh $\mathrm{f} / 2 \mathrm{medium}$, the recycled medium could also efficiently support $C$. vulgaris growth. Among the three flocculants tested, chitosan was ideal owing to its high efficiency, low dosage requirement, short harvesting time, and reutilization of culture medium.

\section{Introduction}

Microalgae are unicellular microscopic organisms that perform oxygenic photosynthesis. They have simple reproductive and cell growth system, allowing superior productivity and long-term survival in various harsh environments ranging from fresh water to salt, ice, or hot springs. Besides, microalgae are adaptable to genetic modification and can grow in non-arable land that can be utilized for algal biomass cultivation. Microalgae are sunlight-driven, fast growing cell factories that are being explored for the synthesis of lipids, proteins, and various high-value products, including docosahexaenoic acid, eicosapentaenoic acid, lutein, astaxanthin, $\beta$-carotene, and phycocyanin (Khan \&Fu 2019, Raslavicius et al. 2018). Thus, these organisms can be potentially used for commercial production of biofuel (e.g., biodiesel, bioethanol and biogas), human and animal nutrition, pharmacy, and cosmetics, fine chemicals and can also act as a tool for carbon dioxide bioremediation (Zhu et al. 2019, Zhu et al. 2017). In particular, with increasing focus on "organic" and "natural" products, microalgal biotechnology is being increasingly applied in animal feed and nutraceutical markets, which have an annual value of $\$ 31.3$ billion and $\$ 198.7$ billion as of 2016 , and are projected to grow to $\$ 34.2$ billion and $\$ 285.0$ billion in 2021 , respectively (Elder 2017, Pandal \&Zachwieja 2017).

Despite intensive research on microalgae, their commercial application is limited by algal biomass harvest. Microalgae harvesting technologies are challenged by the small size (2-50 $\mu \mathrm{m})$ of microalgal cells, low culture concentration $(0.5 \mathrm{~g} / \mathrm{L}$ in open ponds to $5 \mathrm{~g} / \mathrm{L}$ in closed photobioreactors), negatively charged surface (from 7.5 to $-40 \mathrm{mV}$ ) and high colloidal stability in liquid suspension, and, in particular, high growth rates that require frequent harvesting, when compared with land crops (Mathimani \&Mallick 2018). About 20-30\% of the total production cost can be attributed to microalgae harvesting (Cai et al. 2019).

Microalgae are usually harvested via energy-intensive methods such as centrifugation, flotation, filtration, and electrical methods (Singh \&Patidar 2018). However, flocculation is employed on larger scales because of its cost effectiveness and simple operation (Singh \&Patidar 2018). Chemicals called flocculants, including metal salts, alkaline flocculants, and cationic polymers, can induce flocculation by charge neutralization, sweeping, bridging, and electrostatic patch (Mathimani \&Mallick 2018). Among them, metal salts provide positive charges to neutralize the negative charges that reduces electrostatic repulsive force between the microalgal cells causes destabilization of microalgal suspension, followed by agglomeration of microalgae, and are used for harvesting 
a wide range of microalgal spices (Mathimani \&Mallick 2018). Alkaline flocculants cause flocculation predominantly through sweeping mechanism (Besson et al. 2019), while cationic polymer induces flocculation mainly via bridging mechanism (Li et al. 2018). In recent years, many studies had been conducted on harvesting microalgal biomass using flocculants, including aluminium chloride, magnesium chloride, ferric sulfate, sodium hydroxide, chitosan, and cationic starch (Nayak et al. 2019, Pandey et al. 2019, Phasey et al. 2017, Zhu et al. 2020). However, these works had mainly focused on flocculants screening and synthesis, flocculation process optimization, and flocculation equipment design, and the effects of different flocculants on microalgal nutrition contents have not received extensive attention (Wang et al. 2019, Zhu et al. 2020). It must be noted that the microalgal components determine the market value of microalgae and their subsequent utilization. Microalgal biomass, especially lipids content, could be lost during harvesting owing to unexpected delays (Lemos et al. 2016).

During algae harvesting process, a large volume of culture medium must be removed, resulting in huge wastage. Microalgal culture medium not only contains specific amounts of essential carbon, nitrogen, and phosphorus for

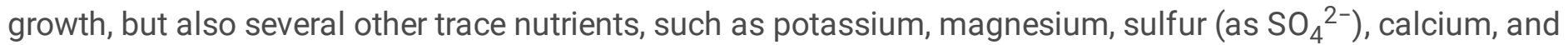
iron, which are essential, despite their small quantities. It has been estimated that the production of $1 \mathrm{~kg}$ of microalgal biofuel will require approximately $3726 \mathrm{~kg}$ of water, $0.33 \mathrm{~kg}$ of nitrogen, and about $0.71 \mathrm{~kg}$ of phosphorus, if the remaining nutrients from algal cultivation are not recycled back into the system (Yang et al. 2011). Recycling of the algal culture medium can save up to $84 \%$ of water and $55 \%$ of essential nutrients such as nitrate and phosphate required for microalgal growth (Yang et al. 2011). Moreover, reuse of the nutrient resources needed for microalgal cultivation is the simplest method of reducing the net requirement for commodity fertilizers for algal biomass. Therefore, recycling of the cultivation medium after harvesting of microalgal biomass is necessary for economical and sustainable production of microalgal biomass. Although there are many reports on the utilization of different flocculants, only a very few have addressed the reusability of culture medium after microalgae harvest (Yang et al. 2011).

In the present study, microalgae harvesting using the flocculation method was evaluated based on the harvesting efficiency of the flocculants, and the reusability of the culture medium after harvesting of microalgae was examined. Furthermore, the effect of harvesting methods on microalgal biomass productivity was also investigated. Flocculants, ferric sulfate, sodium hydroxide, and chitosan, with different flocculation mechanisms, including neutralization, sweeping, and bridging, respectively, were used to harvest the marine microalga Chlorella vulgaris. Floc characteristics such as flocculation efficiency, concentration factor (CF), and flocs morphology were studied, and the microalgal biomass contents, including carbohydrates, proteins, and lipids, were compared between natural sedimentation and after flocculation. Besides, the effect of harvesting methods on algal growth was also observed using recycled medium.

\section{Materials And Methods}

\section{Strain and culture condition}

The alga $C$. vulgaris was obtained from Algae Culture Collection at Laboratory of Applied Microalgae Biology, Ocean University of China (Qingdao, China). The strain was cultivated in f/2 medium in seawater (Guillard 1975), and grown at $25 \pm 1{ }^{\circ} \mathrm{C}$ under 12 -h light/dark cycle and $75 \pm 5 \mu \mathrm{mol} / \mathrm{m}^{2}$.s light intensity. 


\section{Flocculation experiments}

Different dosages of ferric sulfate $(0.1,0.3,0.5,0.7,0.9$, and $1.1 \mathrm{~g} / \mathrm{L})$, sodium hydroxide $(0.1,0.2,0.3,0.4,0.5,0.6$, and $0.7 \mathrm{~g} / \mathrm{L})$, and chitosan $(10,15,20,25,30$, and $35 \mathrm{mg} / \mathrm{L})$ were added to $50 \mathrm{~mL}$ of $C$. vulgaris cultures and mixed at $250 \mathrm{rpm}$ for $2 \mathrm{~min}$, followed by a different settlement period. Using chitosan as flocculant, the $\mathrm{pH}$ of medium was controlled at 6.0 by $1 \mathrm{M} \mathrm{HCl}$. However, the flocculation experiments of ferric sulfate and sodium hydroxide were conducted without $\mathrm{pH}$ adjustments. The supernatant was collected $2 \mathrm{~cm}$ below the surface of the culture, and its optical density (OD) at $680 \mathrm{~nm}$ was determined using a spectrophotometer (UV-1800, Shimadzu, Japan). The flocculation efficiency was calculated as follows:

Flocculation efficiency $(\%)=100 \% \times\left(O D_{0}-O D_{t}\right) / O D_{0}(1)$

Where $\mathrm{OD}_{0}$ and $\mathrm{OD}_{\mathrm{t}}$ are the absorbances of the initial microalgal culture and supernatant after flocculation at $680 \mathrm{~nm}$, respectively.

CF is the ratio of the absorbance of the finial floc to that of the initial culture at $750 \mathrm{~nm}$, which was one of the parameters to evaluate the flocculation efficiency of the flocculant. The CF was determined as follows (Salim et al. 2012):

$\mathrm{CF}=\mathrm{OD}$ sed $/ O D_{\mathrm{to}}(2)$

where $\mathrm{OD}_{\mathrm{t} 0}$ is the absorbance of the initial microalgal culture at $750 \mathrm{~nm}$ and $\mathrm{OD}_{\text {sed }}$ is the absorbance of the floc at $750 \mathrm{~nm}$. The supernatant was removed from the settled cells. Both the supernatant and the remaining settled cells were weighed. The settled cells were resuspended and the OD $750 \mathrm{~nm}$ of the settled cells was measured to determine the biomass concentration in the settled cells.

\section{Characterization of the microalgal flocs}

Algal powder was obtained through vacuum freeze-drying of $C$. vulgaris extracted by centrifugation $(5000 \times \mathrm{g}$ for $15 \mathrm{~min}$ ) or flocculation using the test flocculants, respectively. The total carbohydrates, proteins, and lipids contents in C. vulgaris were measured using anthrone-sulfuric acid (Haldar et al. 2017), Coomassie brilliant blue (Sedmak \&Grossberg 1977), and gravimetric method (Bligh \&Dyer 1959), respectively. Scanning electron microscopy (SEM) micrographs of the harvested microalgal cells were obtained using a scanning electron microscope (JSM-6380LV, Agilent, USA). The algal cells of natural sedimentation and after flocculation were examined by bright optical microscopy (H550S Nikon, Japan).

\section{Recycling of flocculated medium}

After flocculation, the supernatant was separated from the harvested biomass by using $0.22-\mu \mathrm{m}$ filter membrane. Then, the nutrients remaining in the supernatant was determined and their concentrations were adjusted to those in the original $\mathrm{f} / 2$ medium. Subsequently, fresh $C$. vulgaris was inoculated into the recycled medium (including ferric sulfate, sodium hydroxide, and chitosan) or fresh $\mathrm{f} / 2$ medium to investigate the recyclability of the medium for microalgal growth. The growth of $C$. vulgaris was monitored by measuring the OD of the culture at $680 \mathrm{~nm}$ using a spectrophotometer (UV-1800, Shimadzu, Japan).

\section{Statistical analysis}


The results are expressed as the mean value \pm standard deviation (SD) of three replicates. Statistical analysis



\section{Results And Discussion Flocculation process}

Flocculation time and flocculant dosage are the key factors that affect microalgae harvesting. Figure 1 shows the flocculation process using ferric sulfate, sodium hydroxide, and chitosan. All the three test flocculants achieved efficient microalgae harvest. As indicated in Fig. 1, chitosan exhibited the highest flocculation efficiency $(98.8 \% \pm 1.27 \%)$ in shortest time (12 $\mathrm{min})$, followed by ferric sulfate (70 $\mathrm{min})$ and sodium hydroxide (100 min). The rapid settling time achieved by chitosan allows integration of the harvesting process into microalgal culturing in a continuous system, which could possibly improve commercialization of the microalgal industry. In addition, chitosan is non-toxic and can be readily decomposed, which allows its potential use for harvesting microalgae for stringent applications (e.g. human and animal nutrition, pharmacy, and cosmetics).

Maximum harvesting efficiency of $93.4 \% \pm 0.8 \%, 96.5 \% \pm 0.6 \%$, and $98.8 \% \pm 1.3 \%$ was attained using $0.9 \mathrm{~g} / \mathrm{L}$ ferric sulfate, $0.6 \mathrm{~g} / \mathrm{L}$ sodium hydroxide, and $30 \mathrm{mg} / \mathrm{L}$ chitosan, respectively. However, an increase in the flocculant dosage above these optimum levels did not result in further improvement in the flocculation efficiency. In a previous study, Yunos et al. (Yunos et al. 2017) reported that an increase in the flocculant dosage beyond the optimal value will not improve the flocculation-sedimentation process, but possibly re-stabilize the microalgal culture system.

Some previous studies had indicated that a relatively higher dose of flocculants is needed for harvesting marine microalgae (Fabrizi et al. 2010, Jin et al. 2019, Uduman et al. 2010). The optimum dosage of ferric sulfate (0.9 $\mathrm{g} / \mathrm{L}$ ) used in the present study to harvest $C$. vulgaris is much higher than that employed for some freshwater microalgal strains (0.15 g/L ferric sulfate) (Wang et al. 2019). Similarly, the optimum dosage of sodium hydroxide $(0.6 \mathrm{~g} / \mathrm{L})$ used in this study is higher than those utilized for harvesting freshwater strain Nannochloropsis sp. (94.9\%) (Humberto Rojo-Cebreros et al. 2016) and Acutodesmus obliquus (93.5\%) (Lemos et al. 2016) (0.34 and $0.32 \mathrm{~g} / \mathrm{L}$ sodium hydroxide, respectively). Moreover, the optimal dosage of chitosan (30 $\mathrm{mg} / \mathrm{L}$ ) used in the present study for harvesting marine $C$. vulgaris is higher than that employed for harvesting marine Nannochloropsis sp. BR2 (97.01-99.93\%) (22 mg/L chitosan) (Chua et al. 2019) and freshwater Chlorella sp. HS2 (99.6\%) (Nayak et al. 2019) (10 mg/L chitosan), but lower than that used for harvesting marine diatom Chaetoceros gracilis (89\%) (75 mg/L chitosan) (Yamin et al. 2019). It has been indicated that a much higher dosage $(2.5 \mathrm{~g} / \mathrm{L})$ of ferric sulfate is required for harvesting freshwater algal strains (Ch/orella sp. KR-1) than marine algal strains (0.9 g/L) (Zhu et al. 2020). Furthermore, the flocculation efficiency of marine microalgae (Phaeodactylum tricornutum) has been reported to be much higher than that of freshwater microalgae (C. vulgaris) at low dosage (2-16 mg/g dry biomass) of cationic polyacrylamide flocculant (F03801) (Nguyen et al. 2019).

Harvesting efficiency is generally used to indicate the coagulation performance of microalgal harvesting. Moreover, CF is usually utilized to represent enrichment capacity in microalgae harvesting (Mathimani \&Mallick 2018). Figure 1 (d) shows the CF of $0.9 \mathrm{~g} / \mathrm{L}$ ferric sulfate, $0.6 \mathrm{~g} / \mathrm{L}$ sodium hydroxide, and $30 \mathrm{mg} / \mathrm{L}$ chitosan, respectively. The CF of chitosan was significantly higher than that of ferric sulfate and sodium hydroxide, which 
indicated the relatively high compactness of the harvesting microalgae. Furthermore, the flocs formed were not adequately compacted, and the gap between the flocs was considerably large, which resulted in low CF. With regard to chitosan, the flocs formed were compacted with smaller gap between the flocs. As a result, the CF was higher (Fig. 1(d)). However, it has been reported that the CF of sodium hydroxide was lower than that of ferric salts and chitosan in the freshwater microalgae (Lama et al. 2016).

\section{Microscopic analysis}

Figure 2 presents the images of natural sedimentation and after flocculation of $C$. vulgaris under bright optical microscopy. In natural sedimentation, the microalgae appeared as isolated cells that were finely scattered as flocfree cells. However, cultures treated with flocculants (ferric sulfate, sodium hydroxide, or chitosan) showed higher degree of flocs formation. The flocs formed by ferric sulfate and sodium hydroxide were relatively far apart from each other as they were loosely packed. However, the flocs formed by chitosan were the largest, which were closely distributed and patched to form bigger and denser floc network (Fig. 2(d)). In general, the degree of flocs formation among the cells appeared to be strongly correlated with the settling time and flocculation efficiency (Nayak et al. 2019). The floc size was also related to the flocculation mechanism, as this is different for every method (charge neutralization vs bridging vs sweeping) (Lama et al. 2016). Larger and compact flocs produced by chitosan not only led to higher algal removal efficiency, but also faster settling time, when compared with the smaller flocs generated by ferric sulfate and sodium hydroxide, which decreased the sedimentation tank size. This finding is in close agreement with those previously reported (Chekli et al. 2017, Kumari \&Gupta 2020, Li et al. 2015).

The microalgae harvesting process may cause cell disruption, thus, affecting downstream processing. Figure 3 shows the state of microalgal cells of natural sedimentation and after the addition of flocculants. It can be clearly noted that chitosan and ferric sulfate had relatively little influence on the morphology of the flocculated microalgal cells. In contrast, the cell size of $C$. vulgaris dramatically increased after alkaline flocculation, and the cell surface became rough (Figs. 2(c) and 3(c)). Similar results have also been reported in previous studies that revealed that alkaline flocculation caused enlargement of microalgal cells and subsequent cell lysis (Huo et al. 2016). However, Huo et al. (Huo et al. 2016) detected two microalgae that reacted to alkaline flocculant differently, including a marine diatom Chaetoceros muelleri and a freshwater algae Scenedesmus quadricauda. The alkaline flocculation of the marine diatom was mainly caused by $\mathrm{Mg}(\mathrm{OH})_{2}$ rather than calcium phosphate and calcium hydroxide. After harvesting, $\mathrm{Mg}(\mathrm{OH})_{2}$ would attached to the cell wall of algae and make it difficult for biomass utilization in the further process. While for the freshwater algae, alkaline flocculation possible would not damage algal cells, which made it easier for the subsequent utilization of microalgae.

Fractal dimension might provide information on the spatial structure of flocs, which is related to the flocculation mechanism (Miller et al. 2008, Vahedi \&Gorczyca 2011). In natural sedimentation, the $C$. vulgaris cells were homogenously distributed in the suspension (Fig. 4(a)). However, after flocculants addition, the microalgal cells formed flocs and settled down, resulting in a clear separation of microalgal cells from the culture medium. The addition of ferric sulfate increased the instantaneous concentration of particles and improved the collision frequency between the particles, which can contribute to the formation of algal flocs. According to the primary flocculation mechanism of charge neutralization by ferric sulfate, the positive charge of ferric flocculants attracts the negative charge of $C$. vulgaris cells, resulting in flocs that bundle up into compacted and small aggregates (Fig. 4(b)). When compared with the control, sodium hydroxide flocculation resulted in discernible rupture or 
damage of the cells (Figs. 3(c) and 4(c)), which might be beneficial for nutrients extraction (Yap et al. 2014). In contrast, the addition of chitosan resulted in flocs with highly disordered fibrillar structure (Fig. 4(d)). Besides, the flocs were porous with an open and extended three-dimensional structure, which is consistent with the characteristics of bridging (Miller et al. 2008).

\section{Biomass content}

The effects of flocculants on microalgal contents, including carbohydrates, proteins, and lipids, are important to evaluate flocculants. The lipids content in algae is important for biodiesel production (Mathimani \&Mallick 2018), while proteins and carbohydrates are vital raw materials for nutrition, pharmacy, and cosmetics (Khan \&Fu 2019, Raslavicius et al. 2018). In the present study, no significant difference was noted in the contents of total carbohydrates, proteins, and lipids of centrifugation and after flocculation (Fig. 5), which indicated that the flocculants (ferric sulfate, sodium hydroxide, and chitosan) did not affect the algal content, thus, retaining the application value and facilitating subsequent processing and utilization of $C$. vulgaris. Some previous studies noted that several minerals that were not added to the growth medium were also found in the marine Chlorella sp.. These include $\mathrm{Pb}, \mathrm{Cr}, \mathrm{Ba}, \mathrm{Ni}, \mathrm{Sr}$, and $\mathrm{TI}$ (Ju et al., 2012). Moreover, the optimal range of salinity of microalgal growth were $10 \%$ and $20 \%$. Cell shape was also observed to be good in this range of salinity. The marine microalgae can resistance to high osmotic pressure duo to their growing environment. Thus, the higher mineral content would not reduce content of biochemicals. Many studies have also found that sodium hydroxide (Sidney Aleman-Nava et al. 2017, Vandamme et al. 2015), ferric metal (Lemos et al. 2016), and chitosan (Wu et al. 2015) did not influence the biomass composition of microalgae. However, sodium hydroxide has been reported to decrease the lipids content in Acutodesmus obliquus (Lemos et al. 2016), whereas some metal flocculants have been observed to increase the algal lipids content owing to condition stress (Augustine et al. 2019).

\section{Microalgal growth in recycled medium}

The growth of $C$. vulgaris in the recycled medium was approximately the same as that in the fresh culture medium, and there was no obvious difference in the growth trend according to statistical analysis $(p>0.05)$. The results obtained indicated that the culture medium after flocculation could be recycled, which could reduce the algal production cost as well as save water and nutrition resources. Similar findings have also been reported by Wu et al. (Wu et al. 2015), who used chitosan and sodium hydroxide for harvesting Scenedesmus sp. and Scenedesmus obliquus, respectively. Furthermore, low dosage of ferric chloride $(0.5 \mathrm{~g} / \mathrm{L})$ recycled medium has been demonstrated to enhance algal growth (Farooq et al. 2015), whereas high dosage of ferric chloride (1.62 $\mathrm{g} / \mathrm{L}$ ) recycled medium has been found to inhibit algal growth (Li et al. 2019). Thus, the flocculant type and concentration could have a substantial impact on the recycling of culture medium.

\section{Comprehensive comparison of the three flocculants}

The maximum flocculation efficiency was $98.8 \pm 1.3 \%$, and the minimum flocculation time was 12 min under the $30 \mathrm{mg} / \mathrm{L}$ chitosan. Similar flocculation (chitosan) was utilized to flocculation Chlorella sp. HS2, it observed that the flocculation time was higher than this test (Nayak et al. 2019). In our study, a very high flocculation efficiency $(98.8 \pm 1.3 \%)$ was reported for flocculating marine microalgae. Marine microalgae are also utilized to biorefining, because the biomass can be used to produce higher value products, such as astaxanthin and phycocyanin (Mayers et al. 2018). The astaxanthin and phycocyanin was $\$ 110 / \mathrm{kg}$ and $\$ 180 / \mathrm{kg}$ (http://www.alibaba.com). Using this tested flocculation, the higher harvest efficiencies were obtained. Based on this tested flocculation methods, there is a great potential of marine Chlorella used as feedstocks to product valorize higher value 
products. Moreover, processing cost is one of the most important factors that affect algal markets. In the present study, the algae flocculation efficiency of higher dosages of ferric sulfate $(0.9 \mathrm{~g} / \mathrm{L})$ and sodium hydroxide $(0.6$ $\mathrm{g} / \mathrm{L})$ was similar to that of the low dosage of chitosan $(30 \mathrm{mg} / \mathrm{L})$. Table 1 summarizes the cost of materials, mainly based on the forward reports (Lama et al. 2016, Nayak et al. 2019). It can be noted from the table that flocculation of $1 \mathrm{Kg}$ dry biomass of microalgae can be accomplished using the flocculant chitosan for a cost of 94.0 USD, sodium hydroxide for a cost of 75.4 USD, or ferric sulfate for a cost of 71.4 USD. Although chitosan is expensive, its low dosage requirement and rapid settling rate make it attractive for industrial applications. Furthermore, with increasing commercial production, the cost of chitosan might reduce in the near future (Augustine et al. 2017). Thus, chitosan-based flocculation may be practical for producing high valued products owing to the additional revenue incurred, while ferric sulfate and sodium hydroxide could be suitable in biofuel production from microalgae.

\section{Conclusions}

Analysis of the microalgae harvesting efficiency of three flocculants, ferric sulfate, sodium hydroxide, and chitosan, revealed that $30 \mathrm{mg} / \mathrm{L}$ chitosan presented the highest flocculation efficiency of $98.8 \% \pm 1.3 \%$, with shorter flocculation time. The three test flocculants had little influence on microalgal biomass contents. Furthermore, the recycled culture medium could effectively support algal growth, thus reducing production cost, saving water resources, and protecting the environment. Considering the flocculation efficiency, dosage, and cost, chitosan has potential for industrial applications for harvesting microalgae.

\section{Declarations}

Ethics approval and consent to participate Not applicable.

Consent for publication Not applicable.

\section{Availability of data and materials}

The datasets used and analysed during the current study are available from the corresponding author on reasonable request.

Competing interests The authors declare that they have no competing interests.

\section{Acknowledgments}

This work was support by Chinese Scholarship Council of the Ministry of Education (201908120094), and Tianjin Programs of Innovation and Entrepreneurship for undergraduates (202010057158).

\section{Authors' contributions}

All authors contributed to the study conception and design. Material preparation, data collection and analysis were performed by Yu Wang, Chenchen Feng and Xinzhi Zhang. The first draft of the manuscript was written by Jinling Cai and all authors commented on previous versions of the manuscript. All authors read and approved the final manuscript. 


\section{References}

Augustine A, Kumaran J, Puthumana J, Sabu S, Singh ISB, Joseph V (2017): Multifactorial interactions and optimization in biomass harvesting of marine picoalga Picochlorum maculatum MACC3 with different flocculants. Aquaculture 474, 18-25

Augustine A, Tanwar A, Tremblay R, Kumar S (2019): Flocculation processes optimization for reuse of culture medium without $\mathrm{pH}$ neutralization. Algal Research-Biomass Biofuels and Bioproducts 39

Besson A, Formosa-Dague C, Guiraud P (2019): Flocculation-flotation harvesting mechanism of Dunaliella salina: From nanoscale interpretation to industrial optimization. Water Research 155, 352-361

Bligh EG, Dyer WJ (1959): A rapid method of total lipid extraction and purification. Canadian journal of biochemistry and physiology $37,911-7$

Cai W, Zhao Z, Li D, Lei Z, Zhang Z, Lee D-J (2019): Algae granulation for nutrients uptake and algae harvesting during wastewater treatment. Chemosphere 214, 55-59

Chekli L, Corjon E, Tabatabai SAA, Naidu G, Tamburic B, Park SH, Shon HK (2017): Performance of titanium salts compared to conventional FeCl3 for the removal of algal organic matter (AOM) in synthetic seawater: Coagulation performance, organic fraction removal and floc characteristics. Journal of Environmental Management 201, 28-36

Chua ET, Eltanahy E, Jung H, Uy M, Thomas-Hall SR, Schenk PM (2019): Efficient Harvesting of Nannochloropsis Microalgae via Optimized Chitosan-Mediated Flocculation. Global Challenges 3

Elder M (2017): Cattle Feed and Feed Additives: Global Markets to 2022.

Fabrizi L, Jefferson B, Parsons SA, Wetherill A, Jarvis P (2010): The Role of Polymer in Improving Floc Strength for Filtration. Environmental Science \& Technology 44, 6443-6449

Farooq W, Moon M, Ryu B-g, Suh WI, Shrivastav A, Park MS, Mishra SK, Yang J-W (2015): Effect of harvesting methods on the reusability of water for cultivation of Chlorella vulgaris, its lipid productivity and biodiesel quality. Algal Research-Biomass Biofuels and Bioproducts 8, 1-7

Guillard RR (1975): Culture of phytoplankton for feeding marine invertebrates, Culture of marine invertebrate animals. Springer, pp. 29-60

Haldar D, Sen D, Gayen K (2017): Development of Spectrophotometric Method for the Analysis of Multicomponent Carbohydrate Mixture of Different Moieties. Applied Biochemistry and Biotechnology 181, 1416-1434

Humberto Rojo-Cebreros A, Eduardo Morales-Plascencia M, Ibarra-Castro L, Manuel Martinez-Brown J, Alejandra Medina-Jasso M (2016): Flocculation of Nannochloropsis sp induced by sodium hydroxide: flocculation efficiency, viability effect on microalgae and their use as food for rotifers. Latin American Journal of Aquatic Research 44, 662-670 
Huo S, Wang Z, Zhu S, Cui F, Zou B, Wang F, Yuan Z, Dong R, Zhao P (2016): Process Analysis of Alkaline Flocculation Harvesting for Chaetoceros muelleri and Scenedesmus quadricauda. Bioenerg Res 9, $682-690$

Jin X, Bi L, Lyu T, Chen J, Zhang H, Pan G (2019): Amphoteric starch-based bicomponent modified soil for mitigation of harmful algal blooms (HABs) with broad salinity tolerance: Flocculation, algal regrowth, and ecological safety. Water Research 165

Khan S, Fu P (2019): Biotechnological perspectives on algae: a viable option for next generation biofuels. Current opinion in biotechnology $62,146-152$

Kumari M, Gupta SK (2020): A novel process of adsorption cum enhanced coagulation-flocculation spiked with magnetic nanoadsorbents for the removal of aromatic and hydrophobic fraction of natural organic matter along with turbidity from drinking water. Journal of Cleaner Production 244

Lama S, Muylaert K, Karki TB, Foubert I, Henderson RK, Vandamme D (2016): Flocculation properties of several microalgae and a cyanobacterium species during ferric chloride, chitosan and alkaline flocculation. Bioresource Technology 220, 464-470

Lemos J, Vargas J, Mariano A, Kava V, Ordonez J (2016): A flocculation strategy for harvesting high lipid content microalgae biomass, 2016 IEEE Conference on Technologies for Sustainability (SusTech). IEEE, pp. $240-245$

Li L, Zhang H, Pan G (2015): Influence of zeta potential on the flocculation of cyanobacteria cells using chitosan modified soil. Journal of Environmental Sciences 28, 47-53

Li Y, Xu Y, Zheng T, Wang H (2018): Amino acids in cell wall of Gram-positive bacterium Micrococcus sp hsn08 with flocculation activity on Chlorella vulgaris biomass. Bioresource Technology 249, 417-424

Li Y, Zhang Z, Duan Y, Wang H (2019): The effect of recycling culture medium after harvesting of Chlorella vulgaris biomass by flocculating bacteria on microalgal growth and the functionary mechanism. Bioresource Technology 280, 188-198

Mathimani T, Mallick N (2018): A comprehensive review on harvesting of microalgae for biodiesel - Key challenges and future directions. Renewable \& Sustainable Energy Reviews 91, 1103-1120

Mayers JJ, Vaiciulyte S, Malmhäll-Bah E, Alcaide-Sancho J, Ewald S, Godhe A, Ekendahl S, Albers E (2018): Identifying a marine microalgae with high carbohydrate productivities under stress and potential for efficient flocculation. Algal Research 31, 430-442

Miller SM, Fugate EJ, Craver VO, Smith JA, Zimmerman JB (2008): Toward Understanding the Efficacy and Mechanism of Opuntia spp. as a Natural Coagulant for Potential Application in Water Treatment. Environmental Science \& Technology 42, 4274-4279

Nayak M, Rashid N, Suh WI, Lee B, Chang YK (2019): Performance evaluation of different cationic flocculants through pH modulation for efficient harvesting of Chlorella sp. HS2 and their impact on water reusability. Renewable Energy 136, 819-827 
Nguyen LN, Labeeuw L, Commault AS, Emmerton B, Ralph PJ, Johir MAH, Guo W, Hao Huu N, Nghiem LD (2019): Validation of a cationic polyacrylamide flocculant for the harvesting fresh and seawater microalgal biomass. Environmental Technology \& Innovation 16

Pandal NJMRR, bcc Research. Paśko P., Sajewicz M., Gorinstein S., Zachwieja (2017): Nutraceuticals: global markets.

Pandey A, Pathak VV, Kothari R, Black PN, Tyagi VV (2019): Experimental studies on zeta potential of flocculants for harvesting of algae. Journal of Environmental Management 231, 562-569

Phasey J, Vandamme D, Fallowfield HJ (2017): Harvesting of algae in municipal wastewater treatment by calcium phosphate precipitation mediated by photosynthesis, sodium hydroxide and lime. Algal ResearchBiomass Biofuels and Bioproducts 27, 115-120

Raslavicius L, Striugas N, Felneris M (2018): New insights into algae factories of the future. Renewable \& Sustainable Energy Reviews 81, 643-654

Salim S, Vermuë MH, Wijffels RH (2012): Ratio between autoflocculating and target microalgae affects the energy-efficient harvesting by bio-flocculation. Bioresource Technology 118, 49-55

Sedmak JJ, Grossberg SE (1977): A rapid, sensitive, and versatile assay for protein using Coomassie brilliant blue G250. Analytical biochemistry $79,544-52$

Sidney Aleman-Nava G, Muylaert K, Bermudez SPC, Depraetere O, Rittmann B, Parra-Saldivar R, Vandamme D (2017): Two-stage cultivation of Nannochloropsis oculata for lipid production using reversible alkaline flocculation. Bioresource Technology 226, 18-23

Singh G, Patidar SK (2018): Microalgae harvesting techniques: A review. Journal of Environmental Management 217, 499-508

Uduman N, Qi Y, Danquah MK, Hoadley AFA (2010): Marine microalgae flocculation and focused beam reflectance measurement. Chemical Engineering Journal 162, 935-940

Vahedi A, Gorczyca B (2011): Application of fractal dimensions to study the structure of flocs formed in lime softening process. Water Research 45, 545-556

Vandamme D, Beuckels A, Markou G, Foubert I, Muylaert K (2015): Reversible Flocculation of Microalgae using Magnesium Hydroxide. Bioenerg Res 8, 716-725

Wang S, Yerkebulan M, Abomohra AE-F, El-Khodary S, Wang Q (2019): Microalgae harvest influences the energy recovery: A case study on chemical flocculation of Scenedesmus obliquus for biodiesel and crude bio-oil production. Bioresource Technology 286

Wu J, Liu J, Lin L, Zhang C, Li A, Zhu Y, Zhang Y (2015): Evaluation of several flocculants for flocculating microalgae. Bioresource Technology 197, 495-501 
Yamin WA, Shaleh SRM, Ching F, Othman R, Manjaji-Matsumoto M, Mustafa S, Shigeharu S, Kandasamy G (2019): Harvesting Chaetoceros gracilis by flocculation using Chitosan, IOP Conference Series: Earth and Environmental Science. IOP Publishing, pp. 012123

Yang J, Xu M, Zhang X, Hu Q, Sommerfeld M, Chen Y (2011): Life-cycle analysis on biodiesel production from microalgae: Water footprint and nutrients balance. Bioresource Technology 102, 159-165

Yap BHJ, Crawford SA, Dumsday GJ, Scales PJ, Martin GJO (2014): A mechanistic study of algal cell disruption and its effect on lipid recovery by solvent extraction. Algal Research-Biomass Biofuels and Bioproducts 5, 112120

Yunos FHM, Nasir NM, Jusoh HHW, Khatoon H, Lam SS, Jusoh A (2017): Harvesting of microalgae (Chlorella sp.) from aquaculture bioflocs using an environmental-friendly chitosan-based bio-coagulant. International Biodeterioration \& Biodegradation 124, 243-249

Zhu L, Li S, Hu T, Nugroho YK, Yin Z, Hu D, Chu R, Mo F, Liu C, Hiltunen E (2019): Effects of nitrogen source heterogeneity on nutrient removal and biodiesel production of mono- and mix-cultured microalgae. Energy Conversion and Management 201, 112144

Zhu L, Hu T, Li S, Nugroho YK, Li B, Cao J, Show P-L, Hiltunen E (2020): Effects of operating parameters on algae Chlorella vulgaris biomass harvesting and lipid extraction using metal sulfates as flocculants. Biomass \& Bioenergy 132

Zhu LD, Li ZH, Guo DB, Huang F, Nugroho Y, Xia K (2017): Cultivation of Chlorella sp. with livestock waste compost for lipid production. Bioresource Technology 223, 296-300

\section{Table}

Table 1 The economic comparison of flocculants 


\begin{tabular}{|c|c|c|c|c|c|c|c|c|}
\hline microalgae & $\begin{array}{l}\text { Flocculant } \\
\text { type }\end{array}$ & $\begin{array}{l}\text { Flocculant } \\
\text { concentration }\end{array}$ & $\begin{array}{l}\text { Flocculation } \\
\text { time (min) }\end{array}$ & $\begin{array}{l}\text { Flocculation } \\
\text { efficiency } \\
(\%)\end{array}$ & $\begin{array}{l}\text { Concentration } \\
\text { factor }\end{array}$ & $\begin{array}{l}\text { Flocculant } \\
\text { cost } \\
\text { (USD/ton) }\end{array}$ & $\begin{array}{l}\text { Cost } \\
\text { (USD/kg dry } \\
\text { microalgae) }\end{array}$ & Reference \\
\hline \multirow[t]{4}{*}{ C. vulgaris } & $\begin{array}{l}\text { ferric } \\
\text { sulfate }\end{array}$ & $0.9 \mathrm{~g} / \mathrm{L}$ & 70 & $93.4 \pm 0.8$ & $4.4 \pm 0.3$ & 150 & 71.4 & This test \\
\hline & $\begin{array}{l}\text { sodium } \\
\text { hydroxide }\end{array}$ & $0.6 \mathrm{~g} / \mathrm{L}$ & 100 & $96.5 \pm 0.6$ & $4.8 \pm 0.1$ & 380 & 75.4 & This test \\
\hline & chitosan & $30 \mathrm{mg} / \mathrm{L}$ & 12 & $98.8 \pm 1.3$ & $8.0 \pm 0.1$ & 6000 & 94.0 & This test \\
\hline & $\begin{array}{l}\text { sodium } \\
\text { hydroxide } \\
\text { (DAF } \\
\text { system) }\end{array}$ & $0.1 \mathrm{~g} / \mathrm{L}$ & 60 & 80 & - & 380 & - & $\begin{array}{l}\text { (Besson } \\
\text { et al. } \\
2019 \text { ) }\end{array}$ \\
\hline Chlorella sp. HS2 & $\begin{array}{l}\text { aluminium } \\
\text { sulfate }\end{array}$ & $0.2 \mathrm{~g} / \mathrm{L}$ & 30 & 93.8 & - & 150 & 12.2 & $\begin{array}{l}\text { (Nayak et } \\
\text { al. 2019) }\end{array}$ \\
\hline Chlorella sp. HS2 & $\begin{array}{l}\text { ferric } \\
\text { chloride }\end{array}$ & $0.3 \mathrm{~g} / \mathrm{L}$ & 30 & 98.83 & - & 350 & 40.5 & $\begin{array}{l}\text { (Nayak et } \\
\text { al. 2019) }\end{array}$ \\
\hline Chlorella sp. HS2 & $\begin{array}{l}\text { ferric } \\
\text { sulfate }\end{array}$ & $0.35 \mathrm{~g} / \mathrm{L}$ & 30 & 97.3 & - & 150 & 20.6 & $\begin{array}{l}\text { (Nayak et } \\
\text { al. 2019) }\end{array}$ \\
\hline Chlorella sp. HS2 & chitosan & $10 \mathrm{mg} / \mathrm{L}$ & 30 & 99.6 & - & 6000 & 22.9 & $\begin{array}{l}\text { (Nayak et } \\
\text { al. 2019) }\end{array}$ \\
\hline $\begin{array}{l}\text { Chlorella } \\
\text { pyrenoidosa }\end{array}$ & egg shell & $0.1 \mathrm{~g} / \mathrm{L}$ & 60 & 99 & - & - & - & $\begin{array}{l}\text { (Pandey } \\
\text { et al. } \\
2019 \text { ) }\end{array}$ \\
\hline $\begin{array}{l}\text { Chlorella } \\
\text { pyrenoidosa }\end{array}$ & LACC & - & 60 & 95 & - & - & - & $\begin{array}{l}\text { (Pandey } \\
\text { et al. } \\
\text { 2019) }\end{array}$ \\
\hline $\begin{array}{l}\text { algae in municipal } \\
\text { wastewater }\end{array}$ & $\begin{array}{l}\text { calcium } \\
\text { oxide }\end{array}$ & $354 \mathrm{mg} / \mathrm{L}$ & 30 & 93 & - & 120 & $\begin{array}{l}50.0 \mathrm{USD} / \mathrm{L} \\
\text { culture }\end{array}$ & $\begin{array}{l}\text { (Phasey } \\
\text { et al. } \\
2017 \text { ) }\end{array}$ \\
\hline
\end{tabular}

Flocculants cost based on bulk price estimations ferric sulfate $=150$ USD/ton (Nayak et al. 2019), sodium hydroxide $=380$ USD/ton $($ Lama et al. 2016) , chitosan $=6000$ USD/ton (Nayak et al. 2019), ferric chloride $=350$ USD/ton (Nayak et al. 2019), aluminium sulfate $=150$ USD/ton (Nayak et al. 2019), calcium oxide = 120 USD/ton (Phasey et al. 2017).

\section{Figures}



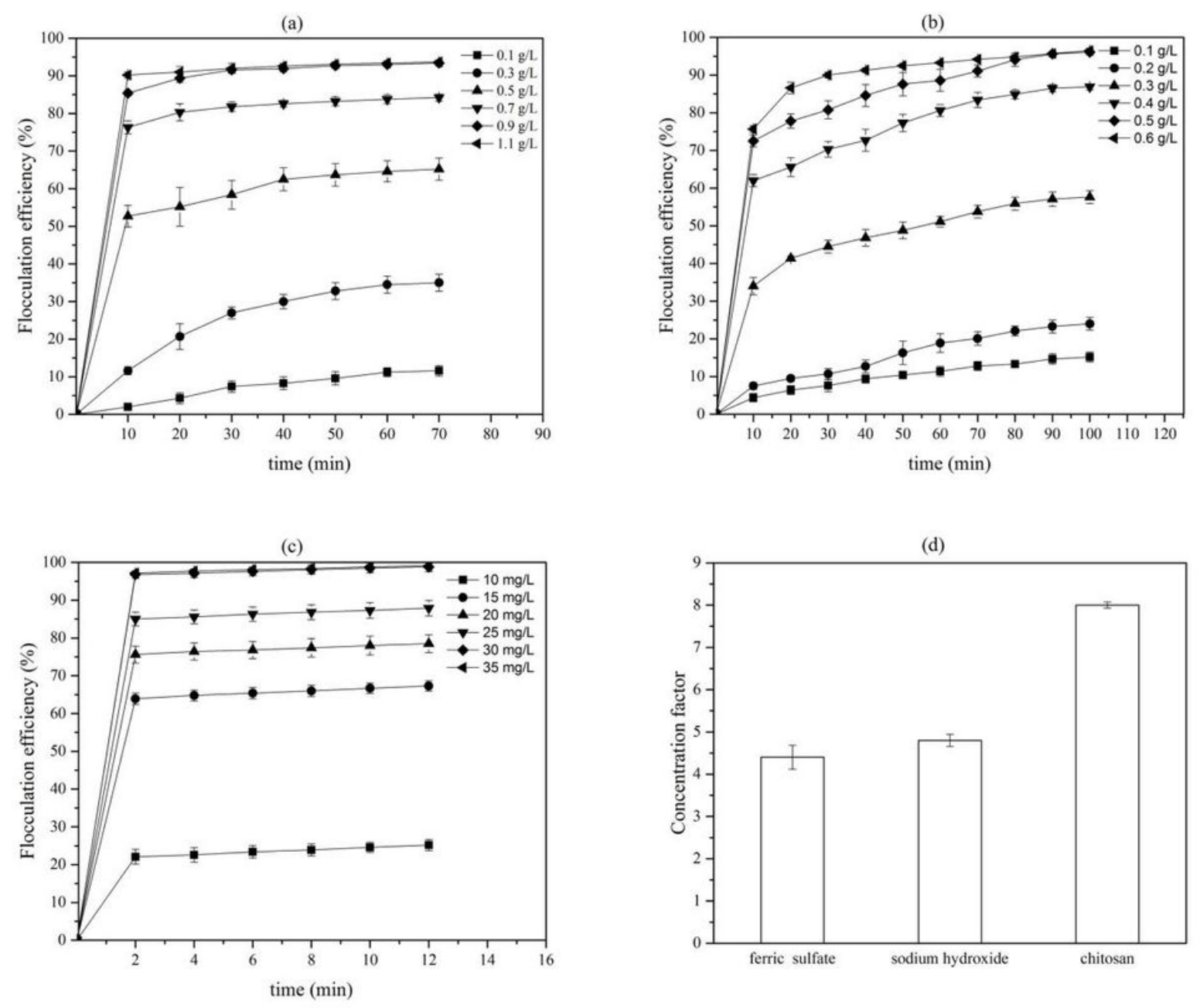

Figure 1

Flocculation efficiencies of C. vulgaris. (a) ferric sulfate, (b) sodium hydroxide, (c) chitosan, (d) Concentration factor at $0.9 \mathrm{~g} / \mathrm{L}$ ferric sulfate, $0.6 \mathrm{~g} / \mathrm{L}$ sodium hydroxide and $30 \mathrm{mg} / \mathrm{L}$ chitosan. Data here represents the mean values of three replicates and bar shows the standard deviation. 

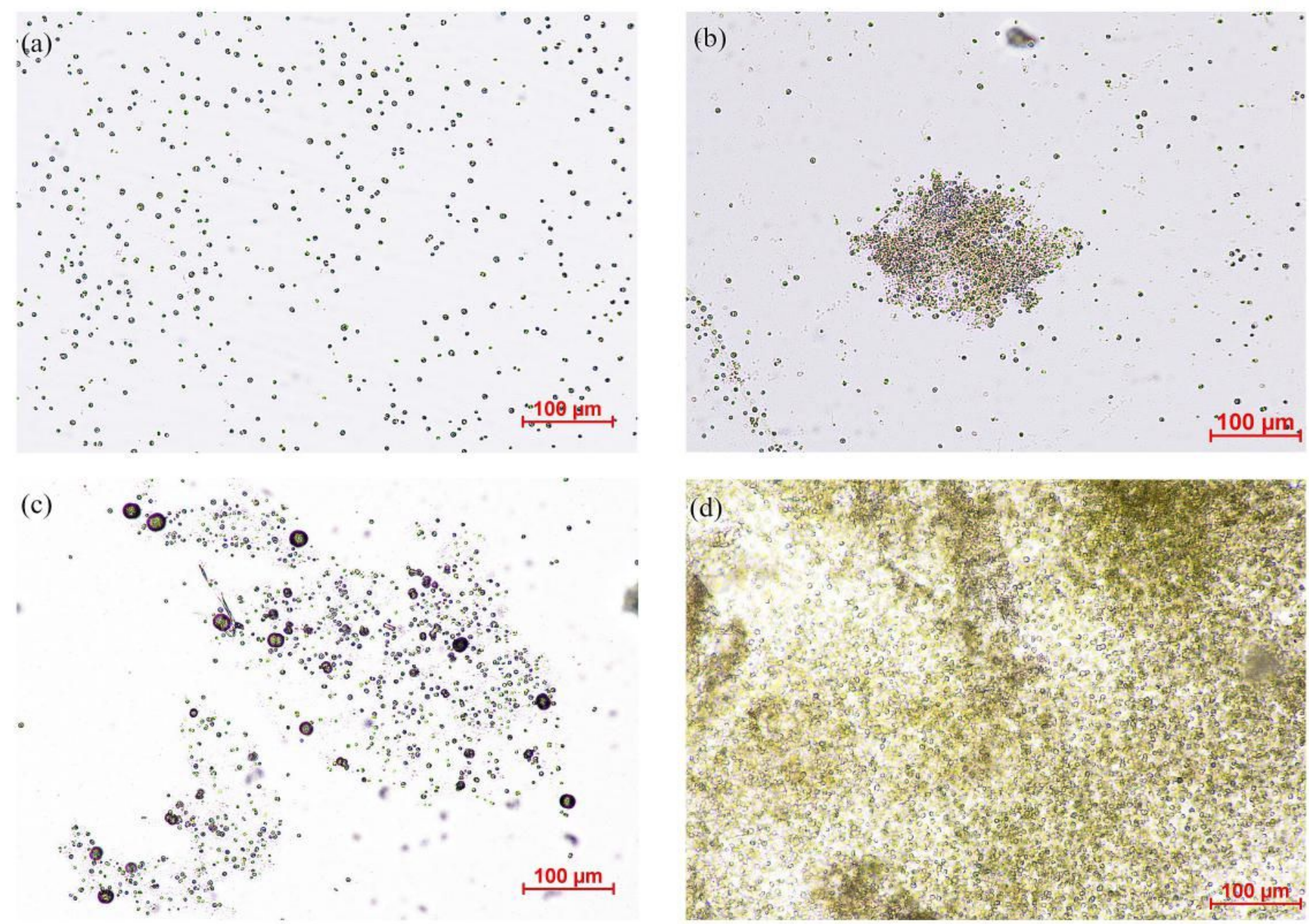

\section{Figure 2}

Microscopic images of natural and flocculated C. vulgaris. (a) natural sedimentation, (b) ferric sulfate, (c) sodium hydroxide, (d) chitosan. 

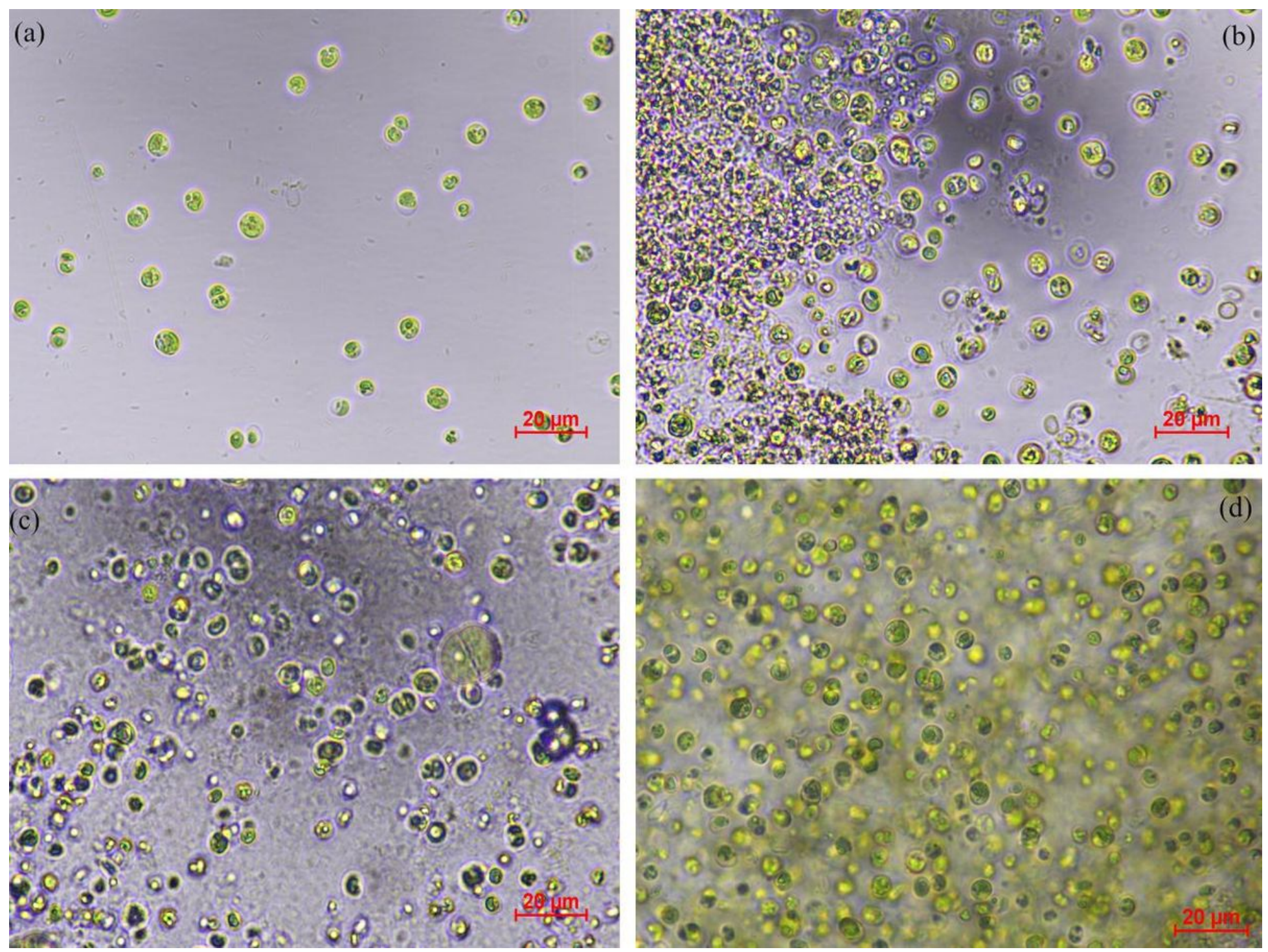

Figure 3

Integrity of microalgae cells. (a) natural sedimentation, (b) ferric sulfate, (c) sodium hydroxide, (d) chitosan. 

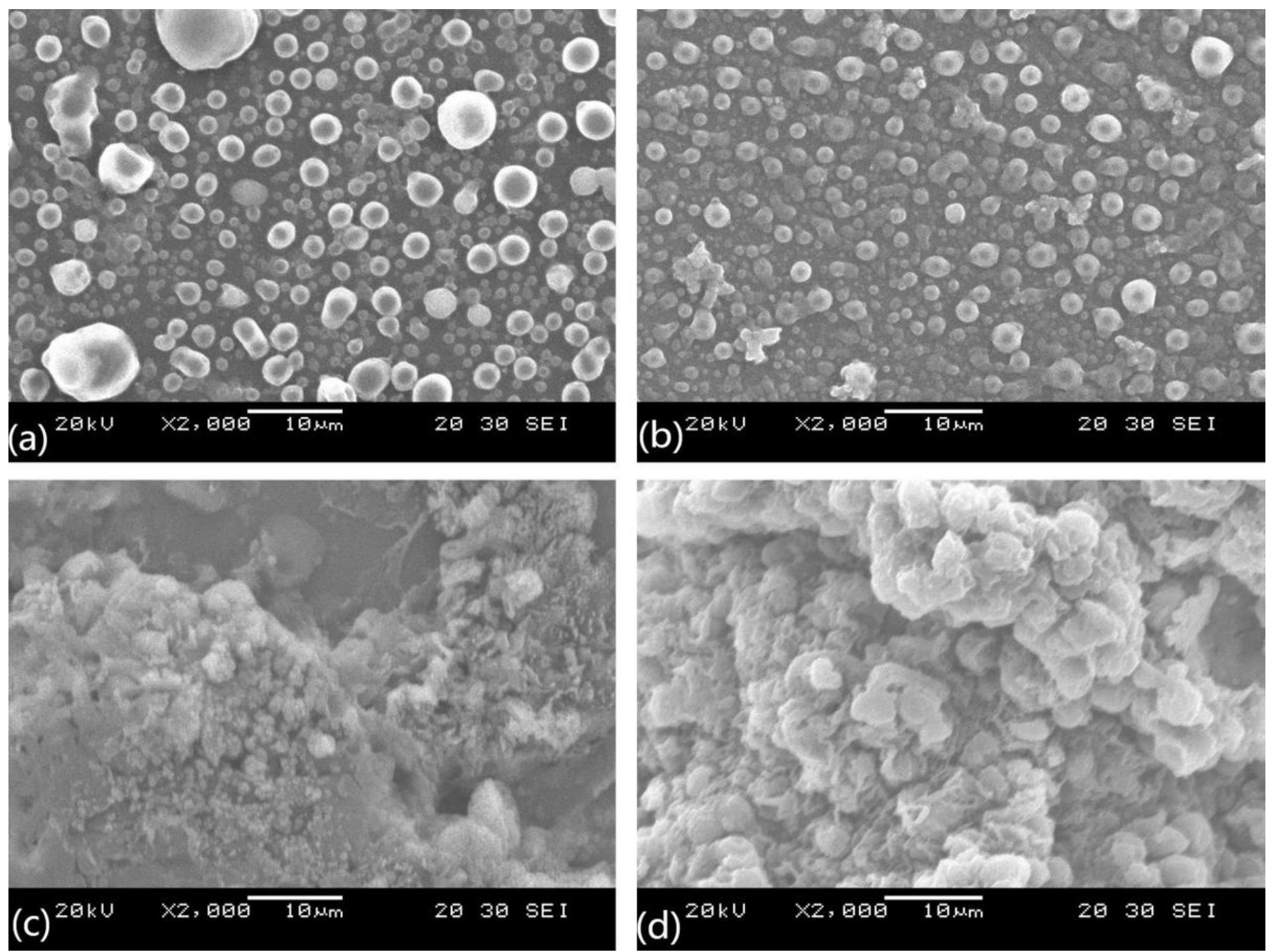

Figure 4

SEM morphology of C. vulgaris. (a) natural sedimentation, (b) ferric sulfate $(0.9 \mathrm{~g} / \mathrm{L})$, (c) sodium hydroxide $(0.6$ $\mathrm{g} / \mathrm{L})$, (d) chitosan $(0.03 \mathrm{~g} / \mathrm{L})$. 


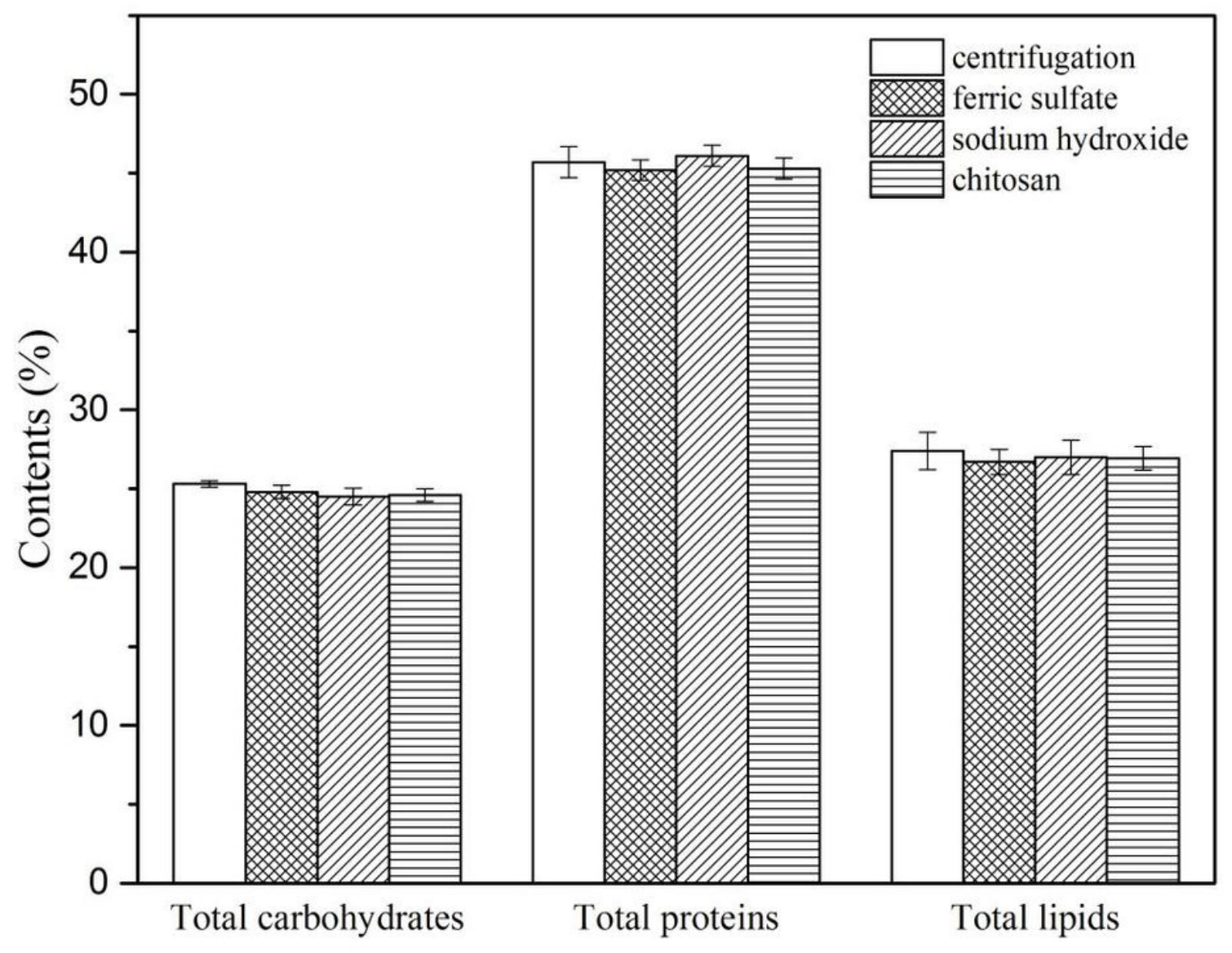

Figure 5

Comparison of material contents after flocculation. 


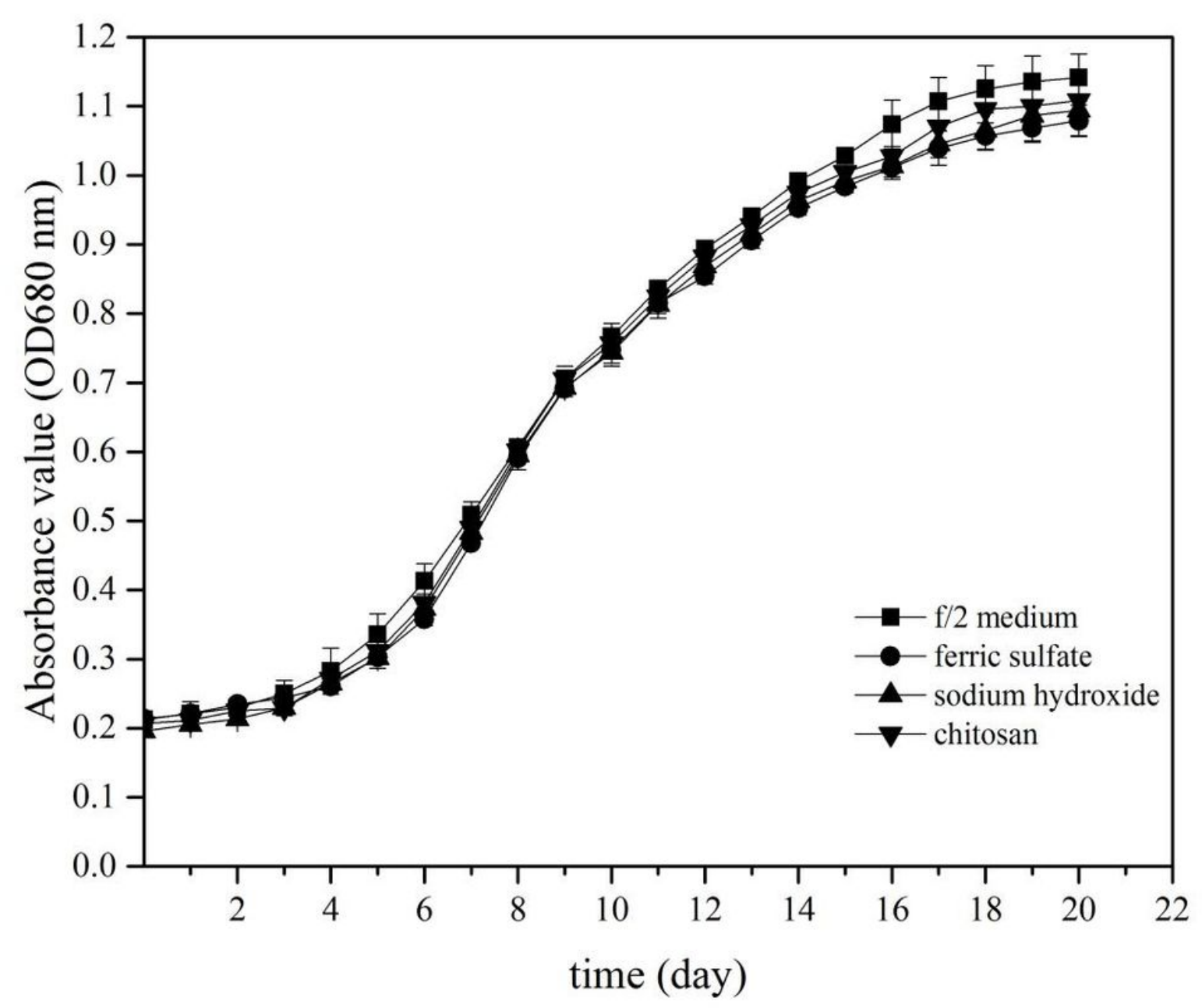

Figure 6

Growth of algal cell in recycled medium. 